\title{
Gerakan Keberagamaan Baru: Mitosis dan Reflikasi Pantekosta Amerika ke Indonesia
}

\author{
Elia Tambunan \\ Sekolah Tinggi Teologi Salatiga \\ elia.tambunan@gmail.com \\ Samuel Kelvin Ruslim \\ Magister Theologia Sekolah Tinggi Teologi Real Batam \\ drsamuelkelvin@gmail.com
}

\begin{abstract}
It is a historical problem if the Pantecostal Church in Indonesia is generalized as a direct result of the Azusa Street global Pentecostal movement. The academic argument of this paper explains, that church, (where W.H. Offiler and W.W. Patterson are the pioneers from American stream even for other Pentecostals today), has its own wordview and is popular in the American Pacific Northwest, it cannot be generalized. Through literature study research using qualitative source criticism techniques, and by prioritizing primary sources, and using socio-religious movement theory, the answer to why, and in what social setting in America and Indonesia, the ideas of Pantecostalism emerged, here is being presented. This provides a new understanding, the history of the idea of religious man is also the history of the Americanization of Pantecostals in the world and even Indonesia. It should be seen, Pantecostals have their own modes of religiousity in their uniquely enterprises to form a theological identity and religious mode although there are similarities with others. Pantecostal studies with GPdI as the focus of study of transnational religious social movements saving sinners are fit to put in the study of Pentecostalism and global religious studies.
\end{abstract}

Keywords: America-Indonesia; christian religious movement; mitosis and replication; pantecostal church in indonesia

\begin{abstract}
Abstrak
Adalah masalah secara sejarah apabila Gereja Pantekosta di Indonesia digeneralisasi sebagai hasil langsung gerakan Pentakosta global Azusa Street. Argumen akademik tulisan ini memaparkan, gereja itu, (di mana W.H. Offiler dan W.W. Patterson sebagai pionir dari arus Amerika bahkan bagi Pentakostal lain hari ini), memiliki wordview sendiri dan popular di Pacific Northwest Amerika tidak bisa disamaratakan. Lewat penelitian studi literatur dengan teknik kritik sumber secara kualitatif, dan dengan mengutamakan sumber primer, serta memakai teori gerakan sosial keagamaan, di sini tersingkap jawaban mengapa, dan dalam latar sosial Amerika dan Indonesia seperti apa ide-ide Pantekosta timbul. Ini memberikan pemahaman baru, sejarah ide tokoh agama adalah juga sejarah amerikanisasi Pantekosta dunia bahkan Indonesia. Perlu dilihat, Pantekosta memiliki mode tersendiri dalam usaha-usaha untuk membentuk identitas teologis dan mode keberagamaan meskipun ada similaritas dengan lainnya. Studi Pantekosta dengan GPdI sebagai fokus kajian dalam gerakan sosial keagamaan transnasional untuk menyelamatkan manusia berdosa tepat dimasukkan ke dalam studi Pentakostalisme dan studi agama global.
\end{abstract}

Kata Kunci: Amerika-Indonesia; gerakan keberagamaan kristen; gereja pantekosta di indonesia; mitosis dan reflikasi 


\section{Pendahuluan}

Keberagamaan, (dalam tulisan ini dimaknai sebagai kesalehan hidup yang ditandai dengan kepatuhan dan pengabdian terhadap gereja), apa pun bentuknya, misalnya doktrin adalah konfigurasi (merujuk kepada bentuk, wujud untuk menggambarkan) ide-ide para pemikirnya yang kerapkali dilabeli sebagai pionir direproduksi terus-menerus. Ide pionir, termasuk pemikiran akan hal-hal teologis, selanjutnya akan mengalami transmisi (terus ditularkan dan disebarkan tak kunjung henti) baik ke tokoh lain maupun umat pengikut. Pemikiran teologis tersebut kemudian diyakini dan dipraktekkan oleh komunitas umat beragama. Artinya, ideide teologis keagmaan bersifat sangat konfiguratif dan transmisif adanya yang kemudian menjadi doktrin. Maka, doktrin tak pernah telah menjadi an sich (maksudnya telah ada pada dirinya sendiri seperti telah tertulis secara harafiah). Seluruh doktrin belumlah sesuatu yang mapan dari awal. Dimulai dengan penerimaan seperti itu atas agama, Harvey Whitehouse melanjutkan dengan membangun teori tentang bagaimana agama diciptakan, diteruskan, dan diubah. Teorinya ada dua "modes of religiousity" yang berbeda, yaitu keberagamaan imajiner sendiri dalam bingkai "self senses" dan doktrinal secara akademik. ${ }^{1}$ Sayang sekali, doktrin keagamaan terlalu diyakini oleh karena "pengilhaman Roh Kudus" atau "turun dari sorga" seperti yang umum di Kristen kelompok Pentakoslisme, seperti disitir oleh Wolfgang Vonday, kelompok ini terlalu mementingkan persaan dan pengalaman dengan perspektif sendiri secara radikal sehingga tidak mementingkan hal-hal ilmiah dalam merumuskan ajaran gereja, lantas seolah-olah telah membarukan ajaran ortodoksi gereja lama. ${ }^{2}$

Yang tidak dipahami oleh penikmat teori tersebut adalah Whitehouse datang dari sisi psikologi beragama bukan gerakan sosial keberagamaan seperti yang akan kami lakukan dalam tulisan ini. Menggunakan teori gerakan sosial dalam studi keagamaan pernah dilakukan oleh John A. Hannigan tahun 1991. ${ }^{3}$ Kerangka kerja gerakan sosial dipakai untuk studi agama sangat membantu untuk membongkar ideide di balik doktrin. Sementara itu, oleh Whitehouse, hal-hal psikologis dimanfaatkan dalam upaya memikirkan apa yang sebaiknya dan seharusnya tertanam di struktur otak komunitas keagamaan justru yang mendorong adanya pengelompokan atau faksi ritual yang melokal, eksklusif dan bahkan hampir-hampir membentuk ideologis keagamaan yang dianut.

Yang tidak pernah ditanyakan adalah mengapa dan apa latar bangkitnya ideide pemikir agama, misalnya dalam gerakan keberagamaan dari Pantekosta Amerika dikonfigurasi dan ditransmisi tak kunjung henti ke Indonesia, seperti pertanyaan penelitian dalam tulisan ini. Pemikiran Kristen Amerika di sini menyodorkan Rev. William Henry Offiler (wafat berumur 81 tahun, tepatnya tanggal 29 September 1957) dari Amerika ke ladang misi Pantekosta di Hindia Belanda (sekarang dikenal

1 Harvey Whitehouse, Modes of Religiosity: A Cognitive Theory of Religious Transmission (Lanham, Maryland: Rowman Altamira, 2004), 61.

2 Wolfgang Vonday, "Pentecostalism and Christian Orthodoxy: Revision, Revival, and Renewal," in Generous Orthodoxies: Essays on the History and Future of Ecumenical Theology, ed. Paul Silas Peterson (Eugene, OR: Wipf \& Stock Publishers, 2020), 217-231.

3 John A. Hannigan, "Social Movement Theory and the Sociology of Religion: Toward a New Synthesis," Sociological Analysis 52, no. 4 (1991): 311-331, doi: 10.2307/3710849. 
Indonesia) diwarisi Gereja Pantekosta di Indonesia (selanjutnya disingkat GPdI) hingga sekarang, sebagai objek kajian. Tulisan ini hendak menampilkan ide pergerakan Pantekosta dari Bapa Gereja GPdI arus Amerika bersifat mitosis (pembelahan) dan reflikasi (pengulangan) ${ }^{4}$ hingga ke Indonesia sekarang. Tetapi seperti apa latar kemunculan ide-ide tersebut, akan dipaparkan dalam pembahasan.

Di tulisan ini, kami membangun argumentasi bahwa studi pemikiran Kristen tidaklah stagnan tetapi mengalami perubahan menjadi sebentuk gerakan sosial keberagamaan baru. Lewat paparan di sini, kami sedang "memanggungkan" satu representasi gerakan keberagamaan Pantekosta dengan GPdI sebagai fokus kajian sangat kaya untuk dimasukkan ke dalam studi Pentakostalisme global yang masih sepi peminat, misalnya jika diukur dari tulisan ilmiah yang dipublikasikan di jurnal maupun buku yang terbit secara internasional. Pengetahuan baru dari sini akan terlihat koherensi akademis GPdI bertalian dengan norma-norma keberagamaan mampu melintasi negara, benua bahkan etnisitas. Representasi tersebut berguna untuk sumbangan pemikiran baru pada pendidikan keagamaan, riset teologi dan studi gerakan keberagamaan melampaui polemik bahkan apalogetik sesama Kristen.

\section{Metode Penelitian}

Dalam penelitian kualitatif ini, kami menggunakan metode penelitian studi literatur dengan mengutamakan sumber data primer yang terkumpul atas telaah serius terhadap tulisan-tulisan Rev. WH. Offiler dan Rev. W.W. Patterson. Dalam sejarah GPdI, keduanya dinisbatkan sebagai Founding Fathers Pantekosta atau BapaBapa Gereja GPdI yang memiliki kedudukan istimewa dalam mengekspor gerakan Pantekosta Amerika ke Indonesia. Penisbatan itu belum lekang hingga sekarang. ${ }^{5}$ Berhubung karena GPdI sebagai fokus kajian dalam studi Pentakosta global seperti kami inginkan lewat tulisan ini, kami menggunakan "Pantekosta" khusus untuk GPdI merujuk legal formal sesuai nomenklatur resmi negara. Sedangkan "Pentakosta" digunakan untuk seluruh denominasi gereja di bawah Persekutuan Gereja-gereja Pentakosta Indonesia (PGPI), satu organisasi Kristen di Indonesia penaung khusus denominasi Pentakosta didirikan tanggal 14 September 1979, sebelumnya disebut Dewan Pentakosta Indonesia (DPI).

Hadir dalam bingkai penelitian studi pemikiran dalam gerakan sosial keberagamaan, kami juga menggunakan studi sejarah dengan kritik sumber. Studi sejarah dengan mengkritisi sumber adalah bagus untuk menyingkap di balik mitosis dan reflikasi Kristen bahkan berguna untuk melakukan analisis sumber-sumbernya. ${ }^{6}$

4 Dalam ilmu biologi, mitosis adalah peristiwa pembelahan sel untuk pertumbuhan dan regenerasi yang identik dengan sel induk semula. Dalam mitosis, sel menyalin DNA, kumpulan dari gen dan merupakan unit hereditas. Anak-anak mendapatkan gen mereka dari orang tua biologis tetapi mereka bukan salinan dari orang tua karena gennya sedikit berubah. Perubahan ini disebabkan oleh meiosis dan mutasi. Mitsuhiro Yanagida, "The Role of Model Organisms in the History of Mitosis Research," Cold Spring Harb Perspect Biol 6, no. 9 (2014), doi: 10.1101/cshperspect.a015768.

${ }^{5}$ Elia Tambunan, Sejarah Sosial Pantekostalisme: Pionir, Dan Konteks Seabad GPdI Dalam Studi Global (Jakarta: BPK Gunung Mulia, 2021), 233-260.

6 Tomislav Dulic, "Peace Research and Source Criticism: Using Historical Methodology to Improve Information Gathering and Analysis," in Understanding Peace Research: Methods and Challenges, eds. Magnus Oberg, Kristine Hoglund (London and New York: Routledge, 2011), 35-46, doi: $10.4324 / 9780203828557$. 
Kritik sumber sejarah sangat tepat digunakan untuk memahami bagaimana proses pemikiran Kristen Amerika membelah hingga Indonesia. Agar itu bisa tersingkap lebih jernih, kami menggunakan kerangka teoritik gerakan sosial keagamaan melintasi batas-batas negara dalam bungkus pelayanan kudus. Oleh Stephen M. Cherry dan Helen Rose Ebaugh dijelaskan, gerakan sosial keagamaan menjelaskan misi global di antara agama-agama berbarengan dengan migrasi massal melalui diaspora agama di mana ide-ide agama telah melakukan perjalanan dunia. ${ }^{7}$ Tetapi dengan konsep tersebut, kami justru tidak bersedia untuk terpancang hanya pada gagasan seorang teoritisi semata agar penggunaannya lebih fleksibel sesuai kebutuhan. Apalagi, kami ingin melibatkan perspektif geopolitik internasional di dalam proses amerikanisasi Pantekosta Indonesia.

\section{Hasil dan Pembahasan}

Sudah lama kehadiran kekristenan secara global menjadi mode pergerakan utama keagamaan bahkan juga menjadi ide-ide inti bagi perkembangan dan perubahan dunia modern. Tetapi terlalu banyak sarjana yang mengglobalisasikan seenaknya timbulnya gerakan Pentakosta modern di dunia, (sekarang, era gerakan itu pada umumnya disebut juga dengan Pentakosta klasik Amerika Utara) tanpa membedakan kawasan dengan benua lainnya seperti Eropa misalnya. ${ }^{8}$ Bila lebih dipersempit untuk gerakan kekristenan Indonesia, Pantekosta tidak bisa dikesampingkan. Jejaring dari Pantekosta Hindia Belanda, Indonesia hari ini dibangun di markas besar di Bethel Temple, Seattle, Washington, Amerika dengan rentangan ladang misi Pantekosta sangat mendunia. Sejumlah ladang-ladang misi tersebut berlokasi di sejumlah kota di beberapa benua. Rentangannya mulai dari Amerika Utara, Amerika Selatan, Asia, Timur Tengah, Afrika, Eropa hingga Australia.

\section{Keagamaan Kristen Baru Amerika}

Harus diketahui, awalnya Pantekosta adalah gejala gerakan sosial keberagamaan urban. Menggejala di tengah kaum kosmopolit pada banyak negara dunia sehingga ada mobilisasi Pantekosta secara kosmopilit yang diusahakan oleh para misionaris di berbagai etnis, ras, bangsa dan benua. Namun sayang sekali halhal itu tidak pernah diketahui publik selama ini. Data empiris mengenai hal itu akan dibahas di sub poin berikut. Agar lebih mudah memahami mengapa dan bagaimana mitosis dan reflikasi Pantekosta Amerika ke Indonesia, terlebih dahulu akan kami hamparkan di sini setting sosial yang ada dengan memasukkannya pada kerangka pikir akademik gerakan keagamaan baru.

Satu gerakan keagamaan baru (sering diistilahkan secara teknis akademik untuk membuat paradigma dan untuk lebih cepat dalam memahami, yakni New Religious Movements). Gerakan juga dikenal sebagai agama baru atau alternatif spiritualitas yang membelah dari kelompok agama atau spiritual yang sudah mapan

7 Helen Rose Ebaugh, Stephen M. Cherry, Global Religious Movements Across Borders Sacred Service (London and New York: Routledge, 2014).

8 Pious H. Nyandoro, "Beyond Charity: Towards a Classic Pentecostal Vision for Promoting an Enterprising Spirit in Britain's Deprived Communities," Journal of the European Pentecostal Theological Association 38, no. 1 (2018): 39-49, doi: 10.1080/18124461.2018.1443735. 
tetapi dalam dunia modern selalu dikategorikan secara periferal dalam budaya agama dominan yang telah diterima masyarakat. Memang, Peter B. Clarke mengakui, tidak ada kriteria tunggal yang disepakati untuk mendefinisikan gerakan keagamaan baru. Selalu ada perdebatan tentang bagaimana istilah "baru" harus ditafsirkan dalam konteks studi agama apalagi definisi teknis spiritualitas. Satu perspektif yang disepahami, itu harus menunjuk agama-agama besar yang mapan seperti Kristen, Yudaisme, Islam, Hindu dan Buddha. Kata "agama baru" lebih pada ekspresi, pergerakan dan perkembangannya yang lebih baru bahkan hingga melampaui batas-batas geografis bangsa dan negara. ${ }^{9}$

Jacob Needleman memaknai gerakan keagamaan baru dengan takarantakaran bagaimana isu-isu keagamaan umat manusia yang sangat sentimen di masyarakat dan budaya di dunia modern atau bahkan postmodern diekspresikan dengan cara yang berbeda atau bahkan serupa. ${ }^{10}$ Sedangkan dengan lebih menekankan dimensi alternatifnya, James R. Lewis melihatnya sebagai sistem kepercayaan alternatif atas kekristenan lama yang terlalu mapan dan strukturalis. Oleh para pionir dengan klaim penggilan Tuhan mengubah dan membawa manusia kembali kepada Tuhan. Kaum terlibat secara kritis cenderung tidak lagi menerima doktrinal Kristen dan tatanan sosial yang telah dipegang secara konvensional, dengan maksud baik sebenarnya, agar gagasan-gagasan Tuhan dapat ditampung dalam kerangka pikir manusia yang lebih terbuka bukan untuk mengubah Tuhan. ${ }^{11}$ Pentakostalisme global sebagai satu gerakan keagamaan baru di daratan Amerika memang tepat diposisikan ke dalam kerangka pikir teoritik tersebut. Terlebih, oleh Synan, Pentakostalisme dimulai di Amerika Utara ditandai oleh kebangkitan Azusa Street 1906 telah menyebar ke seluruh duniau tumbuh dari gejolak hidup religiusitas Amerika dan memanifestasikan elemen Metodisme Wesleyan dan teologi kekudusan menyebar ke seluruh dunia. ${ }^{12}$

Ide Synan tersebut amat generalis adanya sehinga perlu ditinjau ulang. Persoalannya ialah ide-ide seperti itu terlanjur diterima sarjana studi Pentakoslisme salam ini. Bahkan, ada yang menari terlalu jauh mundur hingga Pentakostalisme dinavigasi ke teologi Arius seorang Bapa Gereja abad awal yang dilabeli kaum heresi. Tampil di publik dengan tidak pusing akan tata gereja, pengikut Arius (kemudian dicap sebagai Arianisme) justru mengambil bentuk otonomik sangat longgar terhadap kelompok-kelompok patriakh dalam bingkai asosiasi terstruktur. Dengan dilekatkan kepada arianisme, kaum Pentakostal bahkan kemudia dituding membentuk gereja-gereja modern dalam lansekap mengelompok dengan titik tekan kharisma individual versi sendiri-sendiri, namun justru mampu membarui

9 Peter B. Clarke, New Religions in Global Perspective: A Study of Religious Change in the Modern World (London and New York: Routledge, 2006).

${ }^{10}$ Jacob Needleman, Understanding the New Religions (New York: Seabury Publishers, 1978).

11 James R. Lewis, "Approaches to the Study of the New Age Movement," in Perspectives on the New Age, ed. J. Gordon Melton James R. Lewis (Albany, NY: SUNY Series in Religious Studies, 1992), 2.

12 Vinson Synan, "The Pentecostal Movement in North America and Beyond," Journal of Beliefs and Values 25, no. 2 (2004): 153-165, doi: 10.1080/1361767042000251573. 
komunitas-komunitas masyarakat am untuk menjadi saksi Kristus di dunia yang dianggap tabu oleh gerakan Protestanisme. ${ }^{13}$

Harus diketahui secara benar dalam pembabakan historis. Tidak semua gerakan Pentekosta di dunia menarik garis keturunan mereka ke misi Seymour's Azusa Street atau inisiatif Parham di Topeka, Kansas 1901. Ide menyamaratakan itu sudah lama dilawan, misalnya seperti yang banyak dikatakan oleh Johnson Kwabena Asamoah-Gyadu. ${ }^{14}$ Pentakostalisme global juga tidak seluruhnya secara eksklusif diekspor dari Amerika. Namun hal demikian tidak selalu diajarkan secara benar selama ini sehingga ditangkap secara keliru oleh banyak orang. Sangat banyak sarjana yang meneliti gerakan Pentakosta selama ini, namun masih banyak yang tidak jeli. Dalam studi dokumentasi sejarah Pentakostalisme, asal-usul gerakan selalu ada dalam konteks yang berbeda di seluruh dunia. Apa bila dalam studi Pantekostalisme dengan memasukkan GPdI sebagai fokus riset, maka semestinya tetaplah harus membedakannya dari denominasi lainnya. Tetapi hampir semua sarjana yang berlatar belakang Amerika karena terlalu dipengaruhi oleh supremasi ilmu pengetahuan Amerika maka dalam kajian mereka selalu ada upaya melakukan amerikanisasi. Harus dicatat secara baik, tidak boleh ada upaya untuk mengglobalisasikan ilmu-ilmu kepentakostaan dalam bingkai pengetahuan dengan hanya memasukkan seluruh gerakan Pentakosta kepada cara-cara itu seperti yang pernah diingatkan oleh Anderson. ${ }^{15}$ Memang secara garis besar, seperti diterangkan oleh Lyton Chandomba khususnya dalam konteks Afrika Selatan, umumnya diinisiasi oleh Apostolic Faith Mission (AFM) adalah salah satu hasil dari jangkauan misi Azusa Street, California, Amerika oleh nama-nama besar yang sudah umum direkam sejarah seperti John Graham Lake, Elias Letwaba, Pieter Louis Le Roux, Nicholas Bhengu, Richard Ngidi, Frank Chikane, John Gwanzura (Chihari), Langton Kupara. Tetapi tidak seluruhnya gerakan Pentakostalisme seperti yang diusung oleh mereka masuk ke Afrika. ${ }^{16}$

Yang belum pernah diakui secara publik bahwa munculnya gerakan Pantekosta, baik itu di dunia maupun di Indonesia menemukan momentumnya di tengah terjadi erosi basis kuasa Kristen arus utama Eropa Barat maupun Amerika Utara. Erosi yang dimaksud terjadi pada pengaruh teologi Protestanisme, Presbiterianisme, Anglikanisme, Baptisme, Evangelikalisme, Fundamentalisme. Otoritas mereka dipertanyakan karena dianggap sangat kaku dan mengikat kebebasan manusia yang tengah diterpa ide-ide modernisme. Saat bersamaan itu pula, ide-ide Marxisme di kawasan Eropa Timur sedang ambruk. Sebaliknya, ide-ide

13 R. W. Peacocke E. A. Livingstone, M. W. D. Sparks, The Concise Oxford Dictionary of the Christian Church Third Edition (Oxford, UK: Oxford University Press, 2013), 24, 34, 39, 49.

14 Johnson Kwabena Asamoah-Gyadu, African Charismatics: Current Developments within Independent Indigenous Pentecostalism in Ghana, Studies of Religion in Africa Volume 27 (Leiden: Brill, 2005), 1-8.

15 Allen H. Anderson, “'Origins,'” in Handbook of Pentecostal Christianity, ed. A. Stewart (DelKab, IL: Northern Illinois University Press, 2012), 162-166.

${ }^{16}$ Lyton Chandomba, The History of Apostolic Faith Mission and Other Pentecostal Missions in South Africa (Bloomington, Indiana: AuthorHouse, 2007), 14-15. 
liberalisme dalam aktivitas Kristen di fakultas-fakultas teologi universitas maupun seminari Amerika Utara tengah berkibar. ${ }^{17}$

Dalam situasi geopolitik global seperti ditunjukkan di atas itulah gagasan utama Pantekosta dalam bingkai manusia selamat bersama Tuhan terbangun di dalam kepala Offiler dan Patterson yang terus menemukan momentumnya terbaca dari persebaran gerakan Pantekosta seperti di tabel. Maka dalam melakukan studi Pantekosta harus terlebih dahulu didudukkan dalam konteks sosial urban di sejumlah begara dan benua yang ada secara jelas. Difusi Pantekosta Amerika dimobilisasi Offiler dan Patterson tersebut ke kawasan di luar Pasific Northwest bisa disebutkan di sini, antara lain seperti data berikut:

Tabel 1. Persebaran Gerakan Pantekosta di Dunia

\begin{tabular}{|c|c|c|c|}
\hline No & Kota & Negara & Benua \\
\hline 1 & Managua, Nicaragua; Bogota, Garagoa & Colombia & Amerika Latin \\
\hline 2 & Barbados, Guyana, Trinidad, Tobago & Kepulauan Karibia & \\
\hline 3 & Mexico City, Iztapalapa, Ecatepec, Guadalajara & Meksiko & \\
\hline 4 & $\begin{array}{l}\text { Puerto Limon, Bagaces, Cinco Esquinas, San } \\
\text { Jose, Heredia, Alajuela }\end{array}$ & Costa Rica & \\
\hline 5 & $\begin{array}{l}\text { Fussa, Hokkaido, Kurume, Kyusu, Munakata, } \\
\text { Tachikawa, Tokyo }\end{array}$ & Jepang & Asia \\
\hline 6 & Mongolia, Tiongkok & Cina & \\
\hline 7 & Military Bases Kalgan, Taicung & Taiwan & \\
\hline 8 & Military Bases Phra Nakhon, Bangkok & Thailand & \\
\hline 9 & $\begin{array}{l}\text { Hollandia, (Manokwari Irian sekarang, Papua } \\
\text { New Guinea }\end{array}$ & Papua New Guinea & \\
\hline 10 & Davao, Manila & Philippina & \\
\hline 11 & $\begin{array}{l}\text { Seluruh Kota Keresidenan gementee Hindia } \\
\text { Belanda }\end{array}$ & Indonesia & \\
\hline 12 & Islamabad, Karachi, Muzaffargarh, Lahore & Pakistan & \\
\hline 13 & Distrik Kistna & India & \\
\hline 14 & Bandar Abbas, Tehran, Mashhad, Isfahan & Iran & Timur Tengah \\
\hline 15 & $\begin{array}{l}\text { Kampala, Gulu, Mbarara, Mbale, Jinja, Kasese, } \\
\text { Uganda }\end{array}$ & Afirika Timur & Afrika \\
\hline 16 & Den Haag, Holland Utara dan Holland Selatan & Belanda & Eropa \\
\hline 17 & Lucca, Toscana, Roma & Italia & \\
\hline 18 & Melbourne, Sydney & Australia & Australia \\
\hline 19 & Auckland & New Zealand & \\
\hline
\end{tabular}

Dengan membaca data di atas, kami langsung teringat dengan petuah Mark Hutchinson secara tegas. Adalah fakta bahwa Pantekostalisme telah terbukti selalu berreproduksi dengan pembelahan (inveterately fissiparous), mobile dan adaptif memunculkan kemungkinan bahwa untuk pertama kalinya ada bentuk kekristenan yang tak lagi dapat dipelajari hanya dalam bingkai lokal, regional, dan atau nasional.

17 Alister E. McGrath, The Blackwell Encyclopedia of Modern Christian Thought (New Jersey and London: Blackwell Publishing Ltd., 2017), i-xiii, doi: 10.1002/9781405166539.ch1. 
Studi itu sudah ada di proyek universalis. Itu perlu dipelajari sebagai bagian dari proses umpan balik, dan penguatan dengan mengartikulasikan ide-ide subjektif lokal di aras kekristenan yang selalu menjadi bagian dari proses (as part of a process of) di seluruh dunia. ${ }^{18}$ Lalu, meskipun masih selalu ditempatkan ke dalam jenis aliran-aliran di dalam gereja dalam bingkan gerakan zaman baru secara klasifikatif, oleh Jan Aritonang, Pantekosta disebut-sebut merupakan satu di antara berbagai gerakan baru keagamaan Kristen yang kemunculan dan perkembangannya paling spektakuler abad ke-20.19

Belum ada data yang terverifikasi dari para peneliti untuk melakukan silang data lewat literatur yang ditulis oleh orang yang bukan Pantekosta bagaimana akhirnya gerakan Azusa Street tersebut sampai ke kota Spokane, Seattle, Washington secara lebih detail lagi yang menjadi titik koneksi yang lebih sahih bagaimana Offiler menjadi bagian inti Pantekosta di sana. Meskipun dengan sangat minimnya data yang bisa diperoleh, akan tetapi sudah sangat biasa dilakukan generalisasi jika seluruh fenomena gerakan Pentakosta global di seluruh dunia selalu dikaitkan secara langsung ke Azusa Street, termasuk pula oleh Pantekosta di Indonesia dan kaum Pentakostal lainnya.

Ternyata, ada alasan ambisius dan upaya agar diterima orang lain di baliknya. Itu pernah diungkapkan secara kritis oleh Wayne E. Warner ketika melakukan review buku "Dictionary of Christianity in America." Hal itu dilakukan hanyalah hasrat yang tersembunyi untuk tetap melestarikan tradisi dan kehebatan Azusa Street yang dilebih-lebihkan seperti biasa dilakukan oleh nama-nama pionir, tokoh utama, dan topik-topik yang dipaksakan untuk mewakili kelompok The Assemblies of God America dan gerakan Pentakostalisme global ditempelkan menjadi dorongan agama yang ikut serta dalam membentuk kehidupan dan dunia di seluruh benua agar diterima oleh kelompok Kristen arus utama dunia. Ini adalah klaim buruk yang memperlihatkan sikap ambisius. Padahal, orang akan berkata ketika kelompok yang merasa merepresentasikan Pentakostalisme diterima oleh kelompok Kristen arus utama dunia, orang-orang pergerakan Pentakostalisme tersebut justru semakin kehilangan jati diri, kesaksian sebagai pembeda karena seakan harus terpaksa dikaitkaitkan dengan Kristen arus utama dunia. ${ }^{20}$

Dari minimnya data yang bisa terhimpun hingga sejauh ini juga, tampaknya Offiler memang tidak pernah memiliki kaitan secara langsung dengan gerakan Azusa Street. Misalnya itu bisa terbaca dari data yang ada dari Dan Peterson (gembala sidang gereja terakhir Bethel Temple, Seattle tahun 2003 sebelum akhirnya tutup) hanya menyebut secara generalisasi saja di laman blog pribadinya. Perlu dicatat bahwa api Azusa Street, Los Angeles menyebar ke daerah lain di negara bagian Amerika dalam bentuk kebangkitan yang tidak dapat dihentikan termasuk ke

18 Mark Hutchinson, “The Latter Rain Movement And The Phenomenon Of Global Return," in Winds from the North Canadian Contributions to the Pentecostal Movement (Leiden and Boston: Brill, 2010), 265-283, doi: doi.org/10.1163/ej.9789004185746.i-293.101.

${ }^{19}$ Jan S. Aritonang, Berbagai Aliran Di Dalam Dan Di Sekitar Gereja, Cetakan Ke-15 (Jakarta: BPK Gunung Mulia, 2016), 166.

${ }^{20}$ Wayne E. Warner, "Book Review: Dictionary of Christinity in America Edited by Daniel G. Reid, Robert D. Linder, Bruce L. Shelley, Harry S. Stout, Westmont, Illinois: InterVarsity Press, 1990, p, 1305," A/G Heritage (Springfield, Missouri, 1991), 17, 21. 
Spokane. Orang-orang yang mendengar tentang Tuhan yang bergerak juga ingin melihat orang-orang diselamatkan, disembuhkan dan dibebaskan di wilayah mereka. Daerah ini memiliki sekelompok orang yang menjadi tuan rumah kegerakan Amerika tersebut. Banyak kesembuhan supranatural terjadi dan orang-orang dibaptis dengan Roh Kudus di sana. Tidak diragukan lagi. Dengan menyaksikan peristiwa itu selanjutnya sangat berdampak pada Offiler dan membentuk kehidupan dan pelayanan mereka. ${ }^{21}$

Hingga sekarang, data yang terhimpun lebih banyak bersifat denominatik bahkan sangat hagiografik tentang siapa Offiler relasinya secara langsung dengan Azusa Street serta pioneritas gerakan Pentakostalisme global dari daratan Amerika Utara masih terus-menerus bersifat klaim sepihak. Itu terbaca di laman web resmi www.bfi-online.org kini menjadi properti Bethel Fellowship International. ${ }^{22}$ Data yang dikonstruksi dari cara-cara demikian tersebut kemudian diyakini GPdI begitu saja hingga sekarang. Itu buruk sekali. Apalagi bila dipandang dalam upaya untuk mengenali jati diri, kesaksian hebat Pantekosta ke dunia sebagai pembeda yang distingtif secara tegas.

Di sana dipampangkan, datang dari Nottingham, Inggris ke Kanada kemudian menetap di Kota Spokane, Seattle, tepatnya mulai 10 Agustus 1889, sebelumnya Offiler bekerja sebagai insinyur pipa dan pemanas di Davenport Hotel dan beberapa sekolah. Nottingham ialah kota di wilayah Midlands Inggris bagian Tengah. Terkenal karena perannya dalam legenda Robin Hood dan untuk Museum dan Galeri Seni Nottingham Castle yang dibangun di puncak bukit. Sembari bekerja hatinya terus mencari Tuhan. Beberapa waktu, Offiler tertarik pada serangkaian pertemuan-pertemuan doa yang dilakukan di cottage (pondok wisata yang banyak diminati kaum pesiar) di Spokane. Pertemuan-pertemuan itu sebagian besar terdiri dari orang-orang Kristen Christian and Missionary Alliance. Mereka tekun puasa doa di berbagai tempat. Setelah doa puasa selama sepuluh hari, Tuhan mencurahkan Roh Kudus ke atas mereka. Banyak di antara mereka berbicara dalam bahasa Roh ketika dibaptis Roh Kudus. Peristiwa spiritual itu merupakan perkenalan pertama Offiler atas kebangkitan Kristen Amerika yang sedang menggelombang, meskipun ia tidak langsung menerima baptisan Roh itu. Sebelum semua terjadi, untuk pertama kalinya sebagai "pertobatan sejati pertama" maksudnya lahir baru (born again) dalam pemahaman teologis Pantekosta, suatu hari Offiler melewati pertemuan jalanan (street meeting) Bala Keselamatan oleh Kapten McClellan dan sejumlah relawan Amerika. Minatnya bangkit untuk penginjilan jalanan kota Spokane. Ia lalu mengikuti aktivisme Kristen tersebut ditandai dengan Offiler maju ke altar didoakan.

Belum bisa dipastikan tepatnya kapan. Tahun 1908 di suatu hari, Offiler berjalan di tepian sungai Spokane, ia berjumpa dengan seorang penatua dari jemaat the Apostolic Assembly sedang melakukan ibadah pertemuan di tenda (a local tent

${ }^{21}$ Dan Peterson, "Bethel Temple Heritage Part 2, Bethel Temple History Series," Last Modified, December 2, 2011, Accessed November 25, 2021, https://danwpeterson.wordpress.com/category/bethel-temple-history-series/.

${ }^{22}$ Bethel Fellowship International, "About W. H. Offiler, Bethel Fellowship International," Last Modified 2012, Accessed November 25, 2021, https://www.bfi-online.org/w-h-offiler. 
meeting) yang terbilang besar. Orang tersebut kegirangan atas kedatangan Offiler. Ia bergembira dan mengambil sebotol minyak urapan, dan menuangkan ke atas kepala Offiler sambil mengucapkan "kamu diurapi untuk menjadi pendeta kami." Hal itu dianggap sebagai inagurasi Offiler menjadi pendeta jemaat di Spokane tersebut meskipun dirinya sendiri belum dipenuhi oleh Roh Kudus sama sekali.

Di musim Semi 1914, Offiler pindah dari Spokane ke Glacier National Park, Seattle, Washington untuk bekerja pada bidang yang sama sebagai insinyur pipa dan pemanas di perusahaan the Great Northern. Dari awal, ia merasa tidak lagi berhasrat untuk menjadi pendeta di Spokane. Ia ikut berjemaat di pelayanan The Pine Street Mission Seattle yang menempati ruangan atas salah satu bangunan toko furnitur terletak di the Proctor Building Pine Street nomor 2 tengah Kota Seattle. Oleh adanya persoalan internal dan pendeta gereja tersebut, Offiler diminta menjadi gembala. Sambil tetap menjalani kontrak kerja pada hari Senin hingga Sabtu selama dua tahun di sana, karena semakin merasakan panggilan pastoral, pada hari Mingu ia mengadakan ibadah di tenda besar berlokasi gedung taman baru di bangunan the Proctor Building tersebut dengan wadah pelayanan bernama The Pine Street Mission Seattle. Selama 8 tahun, misi Pine Street berkembang kemudian pindah ke lokasi baru di sudut kawasan Olive nomor 7 kota Seattle. Gereja baru itu mengikuti corak Pantekosta disebut dengan The Pentecostal Mission and Apostolic Assembly. Offiler sukses menarik banyak menjadi jemaat Pantekosta di sana. Pelayanan tersebut berkembang cepat menjadi pusat kebangunan rohani berkelanjutan kemudian berganti nama menjadi Gereja Pantekosta Bethel Temple Seattle.

Secara jujur harus diakui. Memang tak ada data hingga hari ini paling bisa dipercayai apakah Offiler pernah hadir di kegerakan Pentakostaliseme Amerika yang berpusat di Azusa Street. Akan tetapi bisa dipastikan bahwa ia memang benarbenar tidak pernah hadir dan berkunjung ke sana secara langusng ketik aitu dengan memperhatikan tahun yang dilalui dalam hidupnya. Ketika ledakan Azusa Street sejak tahun 1906 hingga mereda pada tahun 1909, ia sendiri baru mengalami baptisan Roh Kudus di kota Seattle tahun 1914. Data yang bisa ditemukan hingga sekarang, Offiler lebih banyak berkenalan dengan tokoh-tokoh sekunder dari ledakan Pentakosta tersebut beberapa tahun kemudian sesudah terjadinya ketuangan Roh Kudus tersebut, yakni pada tahun 1915. David Bernard menuliskan, Offiler dibaptis air secara selam tahun 1915 oleh Gleen A. Cook yang kemudian pada tahun 1908 pernah memulai penggembalaan jemaat Pentakosta secara mandiri di kota Spokane, Washington. ${ }^{23}$

Rev. Glenn A. Cook lahir tahun 1867, awalnya seorang pendeta Baptis Indianapolis, Indiana. Ia bekerja untuk koran harian Los Angeles, California. Di awal kebangkitan Azusa Street tahun 1906, ia mengundurkan diri dari posisinya sebagai jurnalis penuh untuk bekerja penuh waktu dengan William J. Seymour. Cook menangani keuangan dan korespondensi misi Azusa dan membantu penerbitan koran The Apostolic Faith Newspaper. Ada data dari The Apostolic Faith Newspaper, volume 1 nomor 6, Los Angeles, September 1906 yang menyebutkan, selama awal 1907, ia membawa pesan Pentakosta ke Indianapolis, Indiana yang dengan cepat

${ }^{23}$ David K. Bernard, A History of Christian Doctrine Volume Three the Twentieth Century A.D. 1900-2000 (Hazelwood, MO: Word Aflame Press, 1999), 109. 
menjadi pusat gerakan baru. Ia juga mengadakan kampanye sukses di Oklahoma, Arkansas, dan Missouri. April 1914, di Belvedere California, Cook dan Frank Ewart saling membaptis ulang dalam nama Yesus. Pada tahun yang sama, Cook melakukan perjalanan misi ke seluruh kawasan Midwest dan bagian Selatan Amerika Utara untuk memberitakan ajaran nama Yesus. Kemudian, ia bekerjasama dengan Frank Ewart di vacinity Los Angeles selama menahun. Tahun 1948, Cook wafat dan dianggap telah mewariskan doktrin Oneness Pentacostalism bagi dunia. Data saling membaptis sesama kaum Pentakostal tersebut biasa terjadi dalam bingkai misi. Di antara mereka tidak bisa secara otomatis dipahami sebagai fakta kerjasama doktrinal. Apalagi, kala itu mereka belum memiliki gereja secara legal formal.

Untuk diketahui, Cook bersama dengan Robert Edward McAlister seorang pendeta dan penginjil Kanada merupakan salah satu anggota pendiri The Pantecostal Assemblies of Canada. Sebelumnya, keduanya berprofesi sebagai jurnalis dan kemudian menjadi manajer William J. Seymour ketika Azusa Street terjadi. Kemudian hari, perkenalan dengan Cook menjadi jejaring penghubung Offiler untuk menorehkan namanya di kelompok the Assemblies of God Fellowship, satu organisasi masyarakat Pentakosta Amerika terbesar saat itu secara longgar belum dalam wadah legal formal. Organisasi itu mengkeikutsertaan Offiler ke dalam The Third General Council pada Oktober 1915 di Hot Springs, Arkansas, satu pertemuan tahunan untuk tokoh-tokoh Pentakosta Amerika di mana sebagian besar mereka adalah "alumni Azusa Street." Tetapi, jejaring tersebut kemudian putus dampak buruk dari perselisihan terkait dengan rasisme Pentakosta Amerika antara tokoh Pentakosta berkulit hitam dan putih yang mengatasnamakan perbedaan doktrinal. Padahal, Azusa dan majalah Apostolik Faith diterbitkan oleh Afro-Amerika dan William J. Seymour digadang-gadang untuk melakukan integrasi ras dan warna kulit. Banyak yang terlalu yakin jika Pentakostalisme adalah kritik atas rasialisme Amerika.24 Kenyataannya, tokoh gerakan tersebut saling mengklaim telah mendapat pewahyuan baru, misalnya Oneness Pentecostalism dan Assemblies of God berujung ditolaknya Offiler oleh mereka.

\section{Mitosis dan Reflikasi Pantekosta ke Indonesia}

Gerakan Pantekosta arus Amerika yang digagas Offiler pertama masuk ke Indonesia tanggal 23 Februari 1921 melalui dua pelopor yaitu Rev. Cornelius Groesbeek dan Rev. Richard van Klaveren. Selanjutnya, pergerakan ini menjadi cikal bakal GPdI. Dengan diintip dari lintasan waktu sejarah misi dan isi teologi maka ialah sesuatu yang pantas bila GPdI disebut sebagai gereja pelopor atau bahkan gereja induk bagi gereja-gereja Pentakosta lain di Indonesia. Apalagi pada awalnya, semua gereja tersebut adalah hasil "pembelahan DNA" dari Bethel Temple Seattle, Washington digembalakan oleh Offiler kemudian diteruskan oleh menantunya sendiri Patterson sebagai bapak pendidikan Pantekosta. Yang belum tuntas tersingkap selama ini dari latar sosial mana ide-ide pergerakan pionir Pantekosta diajarkan bahkan berdifusi luas di seluruh ladang misi khususnya Indonesia.

24 Erik J. Hjalmeby, "A Rhetorical History of Race Relations in the Early Pentecostal Movement, 1906-1916" (The Graduate Faculty of Baylor University Waco, Texas, 2007), 5. 
Ada data historis yang solid berguna untuk membantu kami dalam upaya memahami ide-ide manusia akan selamat bersama dengan Yesus oleh Offiler berkaitan dengan aktivisme misi Pantekosta Amerika ke Indonesia. Misalnya dalam berita yang dimuat oleh kora Seattle Sunday Times, 15 Maret 1936 halaman 3, sebanyak 3500 orang Amerika jemaat gereja independent tersebut berkumpul di Dermaga Laut Seattle, Washington untuk berdoa, memberkati, dan mengutus kontingen misionaris Bethel Temple ke Indonesia. Ada sebanyak 10 orang lelaki dan perempuan dewasa dan 2 anak-anak diutus ke Hindia Belanda saat itu berlayar dengan kapal uap berbendera Amerika Serikat bermerek Presiden McKinley. Offiler berseru-seru kepada "lautan" manusia tersebut dengan mengatakan, "we pull together" untuk mendoakan kesuksesan para tentara salib Kristus untuk menjangkau dan menyelamatkan orang berdoa di daratan Hindia Belanda manusia, baik pria dan wanita berwarna lumpur coklat (brown men and brown women) untuk Tuhan. ${ }^{25}$ Itu jelas hendak mengatakan ide-ide keselamatan berkorelasi dengan misi, satu misi yang ditarik dari bingkai ide masa depan "Tuhan akan segera datang kedua kalinya," seperti yang dibingkai dalam ilmu teologi sistematis eskatologi dalam konsep premilleniarisme yang sangat ditekankan oleh Pantekosta, yang bisa dibaca dalam catatan harian salah satu pendirinya di Hindia Belanda, misalnya Moesje Alt. ${ }^{26}$

Tidak jauh beda dengan Offiler, Patterson mengkaitkan imajinasi pribadinya untuk menggambarkan proses keselamatan manusia berdosa sebagai aktivisme misi yakni untuk menjangkau dan memberitakan panggilan kepada manusia untuk masuk ke dalam Tubuh Kristus. Orang di luar Amerika demikian juga yang ada di Hindia Belanda, bahkan semua umat manusia mengalami kerusakan rohani secara universal (the universal depravity of mankind). Manusia masih selalu dilihat sebagai manusia berdosa dan digambarkan sebagai anak-anak yang patut dimurkai Allah secara alami (children of wrath by nature). Orang dalam keadaan rusak seperti itu harus diselamatkan oleh kasih karunia Allah yakni melalui iman dan bukan lewat usaha dan pekerjaan maupun perbuatan baik manusia. Keselamatan itu dihasilkan oleh pekerjaan Allah. Manusia berdosa bila bersedia untuk beriman kepada Yesus maka akan mengalami proses ciptaan baru dalam Yesus Kristus. Mereka diperlengkapi dengan kuasa Roh Kudus untuk hidup dalam perbuatan baik. Itulah imajinasi hidup yang benar di dalam Tuhan dalam persepsi teologis Pantekosta. ${ }^{27}$

Ajaran agama sebagai kekuatan sosial makro yang mempengaruhi. Maka untuk tetap memanaskan mesin semangat pergerakan tentu saja menjadi sesuatu yang logis jika tokoh utama membentuk doktrin Pantekosta. Apapun perdebatannya, harus diketahui bahwa pemikiran seseorang selalu bersifat konfiguratif dan transmisif kemudian dikonstruksi secara berkelanjutan untuk menjadi doktrin teologis dari satu gerakan misi, ajaran gereja seperti di dunia Kristen. Sebagai sumber norma dan keyakinan moral, doktrin agama secara historis

${ }^{25}$ Elia Tambunan, Sejarah Sosial Pantekostalisme, , 222-225.

${ }^{26}$ Cees van der Laan, Moesje Alt: 50 Jaar Zendelinge in Nederlands-Indie (Franeker: Uitgverij Van Wijnen, 2016), 95-108.

27 Rev. William West Patterson, Notes on Study of Ephesians (Seattle, Washington: Bethel Temple, Inc., 1932), 5. 
memainkan peran penting di sebagian besar masyarakat dan terus relevan di hampir setiap masyarakat. ${ }^{28}$

Penting untuk mempertimbangkan secara jujur. Meskipun Offiler "mendakudaku," bahwa studi Alkitab yang dibuatnya sendiri adalah hasil "perenungan" pribadi bersama dengan Roh Kudus selama kurang lebih 50 tahun, tetapi adalah hal yang mustahil untuk menghapus seluruhnya latar belakang pengalaman teologis di masa kanak-kanaknya hingga remaja ketika beruia 16 tahun menjadi jemaat gereja Anglikan, (dan bahkan olehnya sendiri mengakui bahwa ia sebagai penganut di Notingham Inggris), ${ }^{29}$ secara bersih dari memori neuralnya. Memang, perlu juga dipertimbangkan secara kritis, seseorang beralih kepada pemahaman teologis lainnya justru seringkali ingin melakukan perlawanan terhadap pemahaman dan pengalaman teologis sebelumnya secara lebih garang lagi. Tampaknya, yang lebih benar, tidak menampilkan sikap arogansi dan lebih berposisi netral ialah bahwa ideide teologi Pantekosta, seperti hasil riset tesis Magister of Art dari Paul R. Berube di School of Theology, Oral Roberts University tahun 1983 adalah hasil pembiakan manusia "breeding" lewat pekerjaan Roh agar selalu tampak rohani saja. ${ }^{30}$

GPdI harus "legowo" ditempatkan sebagai salah satu dari fenomena gerakan keagamaan baru dari pesisir Barat Laut Fasific Amerika Utara yang mengalami kemunculan dan perkembangan menjadi satu jenis baru Pentakosta Klasik yang dalam perkembangannya saya sebut mitosis (pembelahan sel melalui tahapantahapan) dan reflikasi (melalui satu fase dan peristiwa "pembelahan DNA" yang berulang tetapi terus ditransmisikan) sehingga seolah tampak menjadi varian baru sama sekali. Tentu saja GPdI mengalami similaritas dan berarsiran dengan teologi yang dianut oleh gerakan Pentakosta sebelumnya bahkan tidak mungkin seluruhnya lepas dari teologi Kristen secara global.

Ada baiknya memahami penjelasan Marius Nel peneliti dari Research Unit of the Faculty of Theology North-West University agar siapapun yang memberikan perhatian pada Studi Pantakostalisme Indonesia dengan GPdI sebagai objek kajian tidak lagi terus-menerus tinggal dalam perdebatan kusir. Secara membabi buta, gerakan Pantekosta, terutama pada masa-masa awalnya, telah dituduh antiintelektualisme dan kurangnya tradisi teologis yang berkembang, dan hal itu dapat dibenarkan apalagi orang-orang Pantekosta membuat komentar negatif tentang "teologi". Mereka mendefinisikan teologi secara umum secara salah. Uniknya, dengan cara tertentu yang memungkinkan mereka pada saat yang sama untuk menganggap serius usaha teologis mereka sendiri. Maka untuk memahami sudut pandang mereka perlu mempertimbangkan prinsip-prinsip teologis gerakan itu untuk memahami pandangannya tentang teologi. Anti-intelektualisme teologi Pantekosta harus dipahami dalam arti historis sebagai reaksi gerakan terhadap apa yang mereka anggap sebagai bahaya teologi yang mewakili kekakuan doktrinal dan

${ }^{28}$ Raza Mir Harry J. Van Buren III, Jawad Syed, "Religion as a Macro Social Force Affecting Business: Concepts, Questions, and Future Research," Business \& Society 59, no. 5 (2020): 799-822, doi: 10.1177/0007650319845097.

${ }^{29}$ Rev. W.H. Offiler, Lima Pokok Peladjaran Jang Penting (Langowan, Sulut: Sekolah Alkitab Langowan, 1956), 20.

30 Paul R. Berube, "The Emergence And Development Of A New Breed Of Classical Pentecostal" (Oral Roberts University, Tulsa, Oklahoma, 1983). 
formalisme. Sehingga, mereka mengutamakan baptisan Roh dan kehidupan yang dihasilkan, dibimbing oleh Roh dalam kerangka pemaknaan dan perkembangan dimensi spiritual orang percaya seringkali tampak seakan bertentangan dengan kemampuan intelektual. Motif kemunculan Pantekosta yang digerakkan oleh semangat eskatologis premileniarisme dalam ide pionir. Semangat itu menuntut tokoh pergerakan di ladang misi agar masyarakat jauh di luar Amerika kembali ke pengalaman dan kekuatan gereja awal, didorong oleh harapan iman berciri apokaliptik-eskatologis tentang kedatangan Kristus kedua kali sesegera mungkin. ${ }^{31}$

Penjelasan Nel menemukan kebenarannya dalam ide-ide Offiler. Terbukti ada ide-ide liberalisme Kristen Amerika, Theosofi, Abdul Bahaisme, Yogaisme, Hinduisme, Kongfusiusme, Buddhaisme, Yudaisme, Paganisme Kristen Sains, Unitarian, bahkan Mohammadisme, (Islam maksudnya), yang sedang dilawan kala ajaran bagi pergerakan Pantekosta dirumuskan oleh Offiler lebih kurang sebanyak 120 unit. ${ }^{32}$ Ide Offiler untuk merumuskan ajaran Pantekosta untuk menggerakkan pergerakan misionaris memang harus secara serius diletakkan pada konteks bangkitnya liberalisme teologis bertepatan pada jantung kemunduran Kristen Amerika saat itu.

Harus diingat, ketika berbicara tentang liberalisme teologis, kami tidak hanya berbicara tentang semangat keterbukaan, flexibilitas iman atau pikiran bebas tetapi tentang satu gerakan selama awal 1900-an yang menantang dan segera menggantikan substansi doktrin klasik gereja dan pengajaran Alkitab yang banyak diwarisi oleh Methodis, Wesleyan. Liberalisme Amerika juga dapat dipahami sebagai kerangka dasar kehidupan politik yang terus-meneru menuntut nilai hak dan kebebasan individu, membatasi intervensi pemerintah atas hidup pribadi, hak milik pribadi dan pasar bebas, konstitusionalisme dan supremasi hukum lebih tinggi di atas kebutuhan hidup teologis gereja dan masyarakat. ${ }^{33}$ Para filsuf politik liberalisme Amerika ini tanpa disadari telah mengambil posisi dalam teodisi dalam perdebatan keadilan Tuhan dimakzulkan oleh sifat duniawi manusia yang diciptakan. Mereka memuja Pelagianisme yang menyimpulkan kemungkinan kebebasan manusia atas campur tangan keadilan Allah. Demi tujuan politik mereka lantas menolak gagasan moral dan keyakinan teologis. Kaum liberal kontemporer setuju Tuhan tidak diperlukan manusia. ${ }^{34}$

Saat itu, terindikasi secara jelas dampak luas dari liberalisme teologis juga pada keyakinan kaum Metodisme, Evangelis Amerika yang mana liberalisme menyapu bersih sepenuhnya supernatural Injil bagi penebusan orang berdosa, mengurangi tekanan adanya rahmat dan kuasa Allah atas alam semesta, wahyu Ilahi memiliki refleksi atas hidup manusia, iman kepada Kristus untuk mengikuti teladanNya, dan menerima kehidupan baru untuk meninggalkan sifat-sifat manusia lama

${ }^{31}$ Marius Nel, ''Pentecostal Theology' As Contradictio in Terminis: A Perspective on the Past and Present," Scriptura 116, no. 1 (2017): 1-13, doi: 10.7833/116-1-1275.

32 William Henry Offiler, God and His Name: A Message for Today (Seattle, Washington: Bethel Temple, Inc., 1932), 6.

${ }_{33}$ Carol A. Horton, Race and the Making of American Liberalism (New York: Oxford University Press, Inc, 2005), 5.

${ }^{34}$ Eric Nelson, The Theology of Liberalism Political Philosophy and the Justice of God (Cambridge, Massachusetts and London, England: The Belknap Press of Harvard University Press, 2019), x-xii. 
yang buruk. Itu adalah era di mana Amerika mengalami pengalaman sosial yang luar biasadan gejolak intelektual, sesuatu yang oleh sejarah gereja-gereja Protestan juga tidak siap. Periode ini melihat munculnya apa yang dikenal secara historis sebagai "liberalisme teologis," satu gerakan yang menyentuh tidak hanya Metodisme Amerika tetapi juga setiap denominasi besar di Amerika. Pada saat yang sama, periode melihat munculnya apa dikenal sebagai "Injil Sosial" satu upaya oleh gereja-gereja Amerika untuk memenuhi kebutuhan sosial yang mendesak di daerah perkotaan yang tumbuh cepat dan terhadang industrialisasi, imigrasi, dan isu-isu yang terkait dengan manufaktur dan tenaga kerja. Itu adalah era di mana gerejagereja di Amerika menemui kesulitan untuk memobilisasi pergerakan. ${ }^{35}$ Liberalisme modern di gereja, penilaian apa pun yang mungkin diberikan atasnya, bagaimanapun, tidak lagi hanya masalah akademis, juga tidak lagi hanya masalah seminari atau universitas teologi. Serangannya menghujam deras terhadap dasardasar iman Kristen yang dibangun dengan penuh semangat sejak pelajaran Sekolah Minggu oleh mimbar, gereja dan oleh media cetak agama. ${ }^{36}$

Sikap Pantekostalisme tentang teologi serta prinsip-prinsip teologisnya sendiri memandang Kristen Amerika perlu dipahami secara pembalikan dari sisi nurani mereka yang terdalam. Pembalikan ide Pantekosta sangat tak masuk akal memang, tetapi itulah satu jalan masuk terbaik untuk memahami sudut pandangnya pada usaha-usaha teologisnya sendiri di mana mereka mendasarkan teologinya pada pengalaman realitas Tuhan. Kenyataan hidup tidak terlalu menghiraukan keterkaitannya dengan hal-hal akademis. Mereka terasa telah lebih puas apabila narasi Alkitab dijelaskan dalam istilah yang mengarah ke spiritualitas, mempraktekkan kasih baik dalam pikiran maupun hidup tiap saat. Meskipun teologi mereka memiliki kesamaan bobot dengan unsur-unsur tradisional yang sama dengan tradisi Kristen umumnya, tetapi spiritualitas Pantekosta mensyaratkan bahwa teologinya harus didasarkan pada pengalaman langsung dengan Tuhan bukan pada teks akademik. Ini gila. Tetapi, itu aktual dan faktual karena pada saat bersamaan mendefinisikan beberapa doktrin Kristen pada umumnya dengan cara lain. Ada ide lain di kepala mereka secara kolektif yang menekankan hal-hal "ngeroh". Kembali oleh Nel, bagi orang Pantekosta, dipenuhi Roh Kudus sudah puas dan mencukupan diri akan hal Itu. Itu terjadi karena mereka merasa jauh lebih penting dari pada belajar dalam warna akademik. ${ }^{37}$

Pergerakan Pantekosta yang dibangun dalam ide-ide persekutuan orang percaya dianggap adalah studi teologis yang menghidupkan. Itu sengaja dilakukan sebagai upaya distringsi bahwa doktrin Kristen arus utama mati. Dampaknya adalah cara pandang teologi yang relatif kabur terhadap kehidupan. Hidup baru dalam Tuhan diyakini lebih hebat daripada mendapatkan pengetahuan baru. Aneh

35 James V. Heidinger II, The Rise of Theological Liberalism and the Decline of American Methodism (Frankin, Tennessee: Seedbed Publishing, 2017), xiv-xv.

36 John Gresham Machen, Christianity \& Liberalism (Grand Rapids, Michigan: Wm. B. Eerdmans Publishing, 1946), 13.

37 Maurius Nel, "Rather Spirit-Filled than Learned! Pentecostalism's Tradition of AntiIntellectualism and Pentecostal Theological Scholarship," Verbum et Ecclesia 37, no. 1 (2016): 1-9, doi: 10.4102/ve.v37i1.1533. 
memang. Tetapi tabiat buruk Pantekosta secara akademis tersebut tampaknya adalah siklus sejarah berulang mencontoh pionir.

Tegas diakui oleh Offiler terkait dengan persebaran anti intelektualitas dan ilmu modern dalam Pantekosta Amerika ke Indonesia pada masa formatif. Dalam kata pengantar buku "God and His Bible or the Harmonies of Divine Revelation," studi Pantekosta buatannya adalah hasil dari hampir lima puluh bertahun-tahun mempelajari Alkitab secara mendalam dan intensif. Ini adalah hasil tidak hanya dari banyak meditasi dan pikiran suci, tetapi puasa dan doa, dalam menunggu perintah Tuhan. Studi itu dibuat tidak mengikuti garis yang biasa dari ilmu mengajar dan belajar Alkitab modern karena sebagian besar materi pelajaran ialah wahyu langsung dari Roh Kudus. Itu dibuat tanpa kebanggaan, atau kesombongan manusia tetapi dari pengalaman panjang. Ilmu mengajar dan belajar Alkitab modern ialah buatan manusia duniawi yang tidak memiliki nilai rohani di mata Tuhan. Ilmu seperti itu lahir dari daging. Memiliki pengalaman yang menggembirakan dan menginspirasi selama bertahun-tahun sangat menarik lebih hebat dari pengajar dan pengkhotbah modern. Oleh Offiler, pengajar dan pengkhotbah modern dilihat secara buruk karena dianggap telah orang terhilang dalam pemikiran rohani dan tersesat dalam perjalanan mencari Tuhan, bahkan mata rohani mereka buta. ${ }^{38}$ Ide-ide teologi Offiler juga dicetak untuk didistribusikan kepada pendengar programnya di Radio dan bahan utama studi bagi sekolah Alkitab. Dia menerbitkan majalah bulanan yang disebut Pentecost Power dikelola sendiri di rumahnya Halladay Street nomor 352. Ia juga menerbitkan banyak catatan, beberapa pamflet dan buku. Jika digenapkan, total studi Alkitab tulisan Offiler ada sedikitnya ada sebanyak 120 pengajaran Alkitab, ribuan materi khotbah. Offiler sedang mengekspor ide-ide amerikanisasi yang diwajibkan sebagai buku ajar utama di Sekolah Alkitab dan Sekolah Tinggi Alkitab maupun Teologi naungan GPd bahkan hingga sekarang. Ia kemudian pensiun tahun 1948 (kemudian digantikan W.W. Patterson menantunya) tinggal di rumah Bethel Evangelical Park, Mirror Lake, Federal Way, Washington hingga wafat 29 September 1957.

Ide-ide anti ientelektualisme Pantekosta dalam diri Offiler diaffirmasi secara serius oleh Patterson juga ketika memberikan kata pengantar di buku God and His Bible or the Harmonies of Divine Revelation tersebut. Patterson mengatakan bahwa Offiler telah menyajikan cara pendekatan terhadap kebenaran Alkitab yang unik. Banyak tema atau studi Alkitab semuanya berbaur menjadi satu harmoni wahyu Ilahi dan iluminasi membawa kepuasan terdalam ke hati untuk mereka yang benarbenar lapar akan "manna sorgawi datang dari Atas." Ia bahkan membuat klaim secara subjektif bahwa tema atau studi Alkitab adalah bagian dalam wahyu, kehendak dan tujuan Tuhan dan hanya bisa diapresiasi secara utuh. Menurutnya, teologi Pantekosta hanya bisa dipahami oleh orang yang ada dengan sikap rendah hati dan bersedia untuk menyembah Tuhan. ${ }^{39}$

38 William Henry Offiler, God and His Bible or the Harmonies of Divine Revelation (Seattle, Washington: Bethel Temple, Inc., 1946), viii, 10.

39 William West Patterson, "Foreword," in William Henry Offiler, God and His Bible or the Harmonies of Divine Revelation (Seattle, Washington: Bethel Temple, Inc., 1946), 1-2. 
Offiler bahkan membuat klaim untuk melawan teologi Kristen yang ada. Di matanya, sudah terlalu lama orang Kristen hidup dalam kekristenan nominal. Mereka sudah terlalu mudah puas dengan pernyataan-pernyataan kredo. Tetapi, sekaranglah waktunya telah tiba ketika masing-masing orang percaya harus berani untuk bersikap dan memperdengarkan kebenaran untuk dirinya sendiri bukan lagi harus selalu merasa aman untuk mengikuti demikian saja orang-orang cerdas yang berdiri di belakang mimbar suci yang mengaku-ngaku menyampaikan Firman Tuhan seperti yang dikerjakan oleh para pengajar Alkitab dengan ilmu modern. Pengkhotbah modern kehilangan diri dalam labirin pemikiran yang tidak spiritual, dan tersesat dari jalan Tuhan. Mereka adalah pemimpin buta sebagai gejala hari akhir sebagai cara kerja roh anti Kristus dari orang-orang yang sebenarnya adalah mengetahui dan mempercayai Firman Tuhan sebelumnya. ${ }^{40}$

Meskipun demikian sikap anti intelektualisme Pantekosta, uniknya, pengaruh Pantekosta oleh Offiler mendunia. Hasil pelayanannya baik di Amerika Serikat maupun di luar negeri dibaiat sebagai salah satu pionir gerakan Pantekosta modern di Pacific Northwest. Dengan demikian, gerakan Pantekosta tidak bisa bahkan tidaklah tepat untuk digeneralisir secara sama rata dengan seluruh fenomena persebaran Pentakosta Amerika di negara asal terlihat dari persebaran pengaruh ideide teologis Offiler yang mendunia. Meskipun, idenya lebih menguat di bagian tertentu negara bagian Amerika khususnya wilayah Samudra Pasifik di Barat Laut popular dengan sebutan Pacific Northwest.

Kawasan geografis Pantekosta di Amerika belum diketahui oleh publik selama ini meskipun hal itu pernah disinggung secara sekilas oleh David A. Reed seorang Profesor Emeritus of Pastoral Theology and research Professor at Wycliffe College, University of Toronto. Ia menegaskan Bethel Temple Seattle sangat popular di daratan Amerika Utara. Badan misi Pantekosta tersebut memang berbeda secara distingtif dan bersifat gereja independen. Gereja tersebut ialah Pantekosta pertama di Seattle dan menjadi gereja terbesar di antara kelompok Pentakostal kawasan Pacific Northwest mengutus misionaris ke luar Amerika. ${ }^{41}$

Yang tidak boleh dilupakan, sejarah kelompok the Assemblies of God di kawasan pesisir Barat Laut Amerika atau Pacific Northwest, seperti testimoni dari Ward M. Tanneberg dalam karyanya juga sangat kuat. ${ }^{42}$ Ada data di Assemblies of God Heritage Tm, Volume 11 Nomor 2, Summer 1991, halaman 2, 3, dan 22 ketika memberitakan tentang $44^{\text {Th }}$ General Council Issue, pada Juni tahun 1919. Sebanyak 601 pemimpin jemaat gereja dari mereka berkumpul mengadakan The Organizational Meeting of the Northwest District of the Assemblies of God dekat danau Green Lake Seattle, satu tempat berdekatan dengan Mirror Lake Seattle yang menjadi basis pergerakan Pantekosta Amerika awal gagasan Offiler. Sebanyak 70.000 anggota gereja dari Idaho, Oregon, Washington turut larut dalam acara tersebut.

40 William Henry Offiler, God, and His Name A Message for Today Second Edition Five Thousand Books (Kirkland, WA: The City Church, Kirkland, WA, USA Bethel Fellowship International, 2011), 7.

${ }^{41}$ David A. Reed, "From Bethel Temple, Seattle to Bethel Church, Indonesia: The Missionary Legacy of an Independent Church," in Global Pentecostal Movements: Migration, Mission, and Public Religion, ed. Michael Wilkinson (Leiden and Boston: Brill, 2012), 93-115.

${ }^{42}$ Ward M. Tanneberg, Let Light Shine Out: The Story of the Assemblies of God in the Pacific Northwest (Dublin, California: By Author, 1977). 
Perlu ditambahkan data sejarah lain agar tampak balapan Pantekosta Amerika di pesisir Pacific Northwest. Tahun 1919 adalah lini masa sangat historis bagi Pantekosta arus Amerika yang diotaki oleh Offiler. Ketika kelompok the Assemblies of God juga mengadakan Organizational Meeting, maka pada tahun itu pula, di tepian danau Green Lake, Seattle, Offiler mengorganisir Pentecost Bethel Temple Camp Meeting. Acara ini diadakan di bawah sebanyak 145 tenda raksasa yang menjadi tempat penginapan bagi ribuan orang yang ikut. Diklaim dalam pemberitaan majalah Pentecostal Power tahun 1989 kemudian dimuat buku "GPdI Ku GPdI MU GPdI Kita Semua" diterbitkan Majelis Pusat GPdI dalam rangka 90 Tahun GPdI Menyambut Mubes XXXII 2012 halaman 8, ratusan orang bertobat. sebanyak 150 orang peserta menerima baptisan air secara selam dan juga baptisan Roh Kudus serta kesembuhan Ilahi. Di acara tersebut pulalah keluarga Richard van Klaveren dan Cornelis E. Groesbeek mendapatkan penglihatan yang mengamanatkan "panggilan Makdonia" bagi mereka untuk bermisi ke Hindia Belanda. Penjelasan tersebut justru menjadi pintu masuk akademik yang paling sahih untuk mengatakan bahwa memang sejak dari awal masa pembentukan selalu ada rivalitas antara jejaring, ide, aktivisme misi, suksesi, balapan atau pertandingan pastoral baik di internal seluas kawasan Pacific Northwest maupun di kawasan eksternal ladang misi luar negeri antara jaringan Pantekosta dan jaringan the Assemblies of God termasuk di Indonesia.

Pacific Northwest adalah wilayah geografis di Amerika Utara Bagian Barat yang dibatasi oleh perairan pesisir Samudra Pasifik di Barat, juga oleh pegunungan Rocky di Timur. Meskipun tidak ada batas resmi, konsepsi yang paling umum mencakup negara bagian di Oregon, Washington, Idaho, Provinsi British Columbia di Kanada. Beberapa kawasan yang lebih luas mencapai Utara ke Alaska, Yukon, Montana, Wyoming dan juga mencapai bagian Selatan ke California Utara. Perbatasannya juga menyentuh wilayah pesisir barat pegunungan Cascade dan Coast. Hal itu diukur dari kesamaan sebagian sejarah kawasan, budaya, geografi, masyarakat, dan faktor lainnya. Di Pacific Northwest, ribuan penduduk asli tinggal dan mempraktekkan kekayaan tradisi budaya dipengaruhi oleh perbatasan KanadaAmerika Serikat, juga banyak dipengaruhi kultur Inggris seperti dinukilkan sejarawan Kanada, Ken Coates. Di pedalaman Pacific Northwest, masyarakat adat, pada saat kontak dengan Eropa, memiliki keragaman budaya dan masyarakat. Beberapa daerah adalah rumah bagi masyarakat yang bergelut dengan mobilitas sosial tinggi namun terbilang egaliter memiliki kenyataan sosial yang sangat kompleks, makmur, menetap, berkompetisi dengan masyarakat pesisir. ${ }^{43}$ Masyarakat Amerika seperti ini menjadi jemaat pendukung Pantekosta ataupun pendengar siaran radio Pantekosta yang dipancarkan Offiler selama kurang lebih 40 tahun selain mengajarkan teologi Pantekosta yang dikonfigurasi dari seluruh laporan ladang misi dunia.

${ }^{43}$ Ken S. Coates, "Border Crossings," in Parallel Destinies: Canadian-American Relations West of the Rockies, ed. Ken S. Coates John M. Findlay (Washington D.C.: Washington: University of Washington Press, 2002), 3-5. 


\section{Kesimpulan}

Pada akhirnya, dengan mengkaji sejarah ide pionir Pantekosta Amerika bersebaran ke dunia hingga Indonesia membentuk modes of religiousity terkait erat dengan aktivisme misi dan imajinasi kedatangan Yesus ke dua kali secara premileniarisme memperlihatkan satu gerakan keberagamaan baru di dunia. Pantekosta sebagai gerakan keagamaan baru di Indonesia saat ini, justru sebagai hasil dikonfigurasi dan ditransmisi tak kunjung henti dengan mengkaitkan imajinasi pribadi pionir mereka sesuai dengan situasi di konteks sosial liberalisme Amerika saat itu. Secara subjektif teritegrasi dengan klaim pewahyuan Tuhan, mereka mengandaikan orang di luar Amerika mengalami kerusakan rohani secara universal. Manusia diproyeksikan secara kuat sebagai manusia berdosa dan patut dimurkai sehingga harus diselamatkan. GPdI sebagai objek kajian studi Pentakostalisme global, setidaknya dalam studi pemikiran dan gerakan keberagamaan oleh tokoh Kristen Amerika, dalam takaran tertentu mampu memperlihatkan memang bersifat mitosis dan reflikasi. Namun gerakan tersebut dimobilisasi menjadi upaya amerikanisasi untuk membentuk gerakan keagamaan baru yang dibuat tampak orisinal sebagai branding sendiri-sendiri dengan mereproduksi banyak literatur oleh para sarja Pentakosta. Sayangnya, dari kelompok Pantekosta sangat terlambat di bidang tersebut. Sedari awal, oleh Offiler dan Patterson karena terlalu anti intelektual, oleh karena situasi liberalisme Amerika kala itu, maka orang GPdI sengaja dirancang untuk bodoh secara kelimuan mesti tidak bisa dikatakan demikian saja dalam bidang pastoral. Konteks geopolitik Amerika ikut membentuk mitosis dan reflikasi Pantekosta yang bersifat kosmopolit yang melintasi batas-batas geografis hingga ke Indonesia.

Tulisan ini menjanjikan pengetahuan baru. Ide-ide agama mampu memainkan peran penting dalam membentuk etika global pergerakan transnasional Pantekosta yang berkelanjutan. Meskipun, tentu saja sudah ada kajian lain seperti Nimi Wariboko dengan menekankan sisi ekonomi misalnya. ${ }^{44}$ Jika saja orang bersedia untuk mengkritisinya lebih jeli, Wariboko hanya berbicara dalam setting sosial Pentakostalisme Afrika secara khusus. ${ }^{45}$ Apalagi, ia tidak pernah menjadikan Pantekostalisme dengan GPdI dari Indonesia sebagai fokus selama ini seperti upaya kami dalam tulisan ini. Keterbatasan penelitian ini memang ada pada bagaimana relasi ajaran soteriologi Pantekosta dengan panggilan untuk misi pergerakan keberagamaan, seperti yang ada dalam etika Protestan dan semangat kapitalisme yang didokumentasikan oleh Max Weber sosiolog, ekonom, dan politisi Jerman tahun 1904 dan 1905 dan dibahasa Inggriskan oleh sosiolog Amerika Talcott Parsons tahun 1930. Satu sejarah etika pergerakan Kristen yang pernah mampu membangun peradaban Eropa bahkan dunia lewat seperangkat nilai, semangat kerja keras dan kemajuan. Uniknya, oleh Anthony Giddens dilihat, etika dan semangat tersebut justru diinisiasi oleh calling Kristen untuk hidup di dunia sebagai orang yang telah

${ }^{44}$ Nimi Wariboko, Economics in Spirit and Truth: A Moral Philosophy of Finance (New York: Palgrave Macmillan, 2014).

${ }^{45}$ Nimi Wariboko, Nigerian Pentecostalism (New York: University of Rochester Press, 2014). 
diselamatkan seperti dalam ide-ide Lutheranisme dan Calvinisme. ${ }^{46}$ Itu pantas menjadi topik kami dalam tulisan berikutnya. Tentu akan sangat lebih menarik apabila diteliti kembali seperti apa teologi keselamatan manusia versi GPdI yang digagas oleh W. H. Offiler dan suksesor selanjutnya, yakni Rev. William West Patterson kemudian dipahami oleh GPdI sekarang.

\section{Rujukan}

Anderson, Allen H. “'Origins.'” In Handbook of Pentecostal Christianity, edited by A. Stewart, 162-166. DelKab, IL: Northern Illinois University Press, 2012.

Aritonang, Jan S. Berbagai Aliran Di Dalam Dan Di Sekitar Gereja, Cetakan Ke-15. Jakarta: BPK Gunung Mulia, 2016.

Asamoah-Gyadu, Johnson Kwabena. African Charismatics: Current Developments within Independent Indigenous Pentecostalism in Ghana, Studies of Religion in Africa Volume 27. Leiden: Brill, 2005.

Bernard, David K. A History of Christian Doctrine Volume Three the Twentieth Century A.D. 1900-2000. Hazelwood, MO: Word Aflame Press, 1999.

Carol A. Horton. Race and the Making of American Liberalism. New York: Oxford University Press, Inc, 2005.

Chandomba, Lyton. The History of Apostolic Faith Mission and Other Pentecostal Missions in South Africa. Bloomington, Indiana: AuthorHouse, 2007.

Clarke, Peter B. New Religions in Global Perspective: A Study of Religious Change in the Modern World. London and New York: Routledge, 2006.

Coates, Ken S. “Border Crossings." In Parallel Destinies: Canadian-American Relations West of the Rockies, edited by Ken S. Coates John M. Findlay, 3-5. Washington D.C.: Washington: University of Washington Press, 2002.

Dulic, Tomislav. "Peace Research and Source Criticism: Using Historical Methodology to Improve Information Gathering and Analysis." In Understanding Peace Research: Methods and Challenges, edited by Magnus Oberg Kristine Hoglund, 35-46. London and New York: Routledge, 2011.

E. A. Livingstone, M. W. D. Sparks, R. W. Peacocke. The Concise Oxford Dictionary of the Christian Church Third Edition. Oxford, UK: Oxford University Press, 2013.

Giddens, Anthony. "Introduction." In Max Weber the Protestant Ethic and the Spirit of Capitalism Translated by Talcott Parsons with an Introduction by Anthony Giddens, vii-xviii. London and New York: Routledge, 2001.

Hannigan, John A. "Social Movement Theory and the Sociology of Religion: Toward a New Synthesis." Sociological Analysis 52, no. 4 (1991): 311-331.

Harry J. Van Buren III, Jawad Syed, Raza Mir. "Religion as a Macro Social Force Affecting Business: Concepts, Questions, and Future Research." Business $\mathcal{E}$ Society 59, no. 5 (2020): 799-822.

Hjalmeby, Erik J. “A Rhetorical History of Race Relations in the Early Pentecostal Movement, 1906-1916." The Graduate Faculty of Baylor University Waco, Texas, 2007.

46 Anthony Giddens, "Introduction," in Max Weber the Protestant Ethic and the Spirit of Capitalism Translated by Talcott Parsons with an Introduction by Anthony Giddens (London and New York: Routledge, 2001), vii-xviii. 
Hutchinson, Mark. "The Latter Rain Movement And The Phenomenon Of Global Return." In Winds from the North Canadian Contributions to the Pentecostal Movement, 265-283. Leiden and Boston: Brill, 2010.

II, James V. Heidinger. The Rise of Theological Liberalism and the Decline of American Methodism. Frankin, Tennessee: Seedbed Publishing, 2017.

International, Bethel Fellowship. "About W. H. Offiler, Bethel Fellowship International." Last modified 2012. Accessed November 25, 2021. https:/ / www.bfi-online.org/w-h-offiler.

Laan, Cees van der. Moesje Alt: 50 Jaar Zendelinge in Nederlands-Indie. Franeker: Uitgverij Van Wijnen, 2016.

Lewis, James R. "Approaches to the Study of the New Age Movement." In Perspectives on the New Age, edited by J. Gordon Melton James R. Lewis, 2. Albany, NY: SUNY Series in Religious Studies, 1992.

Machen, John Gresham. Christianity E Liberalism. Grand Rapids, Michigan: Wm. B. Eerdmans Publishing, 1946.

McGrath, Alister E. The Blackwell Encyclopedia of Modern Christian Thought. New Jersey and London: Blackwell Publishing Ltd., 2017.

Needleman, Jacob. Understanding the New Religions. New York: Seabury Publishers, 1978.

Nel, Marius. "'Pentecostal Theology' As Contradictio in Terminis: A Perspective on the Past and Present." Scriptura 116, no. 1 (2017): 1-13.

Nel, Maurius. "Rather Spirit-Filled than Learned! Pentecostalism's Tradition of AntiIntellectualism and Pentecostal Theological Scholarship." Verbum et Ecclesia 37, no. 1 (2016): 1-9.

Nelson, Eric. The Theology of Liberalism Political Philosophy and the Justice of God. Cambridge, Massachusetts and London, England: The Belknap Press of Harvard University Press, 2019.

Nyandoro, Pious H. "Beyond Charity: Towards a Classic Pentecostal Vision for Promoting an Enterprising Spirit in Britain's Deprived Communities." Journal of the European Pentecostal Theological Association 38, no. 1 (2018): 39-49.

Offiler, Rev. W.H. Lima Pokok Peladjaran Jang Penting. Langowan, Sulut: Sekolah Alkitab Langowan, 1956.

Offiler, William Henry. God, and His Name A Message for Today Second Edition Five Thousand Books. Kirkland, WA: The City Church, Kirkland, WA, USA Bethel Fellowship International, 2011.

- - - God and His Bible or the Harmonies of Divine Revelation. Seattle, Washington: Bethel Temple, Inc., 1946.

- - - God and His Name: A Message for Today. Seattle, Washington: Bethel Temple, Inc., 1932.

Patterson, Rev. William West. Notes on Study of Ephesians. Seattle, Washington: Bethel Temple, Inc., 1932.

Patterson, William West. "Foreword." In God and His Bible or the Harmonies of Divine Revelation, edited by William Henry Offiler, 1-2. Seattle, Washington: Bethel Temple, Inc., 1946.

Paul R. Berube. “The Emergence And Development Of A New Breed Of Classical 
Pentecostal." Oral Roberts University, Tulsa, Oklahoma, 1983.

Peterson, Dan. "Bethel Temple Heritage Part 2, Bethel Temple History Series." Last modified 2011. Accessed November 25, 2021. https:/ / danwpeterson.wordpress.com/category/bethel-temple-historyseries/.

Reed, David A. "From Bethel Temple, Seattle to Bethel Church, Indonesia: The Missionary Legacy of an Independent Church." In Global Pentecostal Movements: Migration, Mission, and Public Religion, edited by Michael Wilkinson, 93-115. Leiden and Boston: Brill, 2012.

Stephen M. Cherry, Helen Rose Ebaugh. Global Religious Movements Across Borders Sacred Service. London and New York: Routledge, 2014.

Synan, Vinson. "The Pentecostal Movement in North America and Beyond." Journal of Beliefs and Values 25, no. 2 (2004): 153-165.

Tambunan, Elia. Sejarah Sosial Pantekostalisme: Pionir, Dan Konteks Seabad GPdI Dalam Studi Global. Jakarta: BPK Gunung Mulia, 2021.

Tanneberg, Ward M. Let Light Shine Out: The Story of the Assemblies of God in the Pacific Northwest. Dublin, California: By Author, 1977.

Vonday, Wolfgang. "Pentecostalism and Christian Orthodoxy: Revision, Revival, and Renewal." In Generous Orthodoxies: Essays on the History and Future of Ecumenical Theology, edited by Paul Silas Peterson, 217-231. Eugene, OR: Wipf \& Stock Publishers, 2020.

Wariboko, Nimi. Economics in Spirit and Truth: A Moral Philosophy of Finance. New York: Palgrave Macmillan, 2014.

- - - . Nigerian Pentecostalism. New York: University of Rochester Press, 2014.

Warner, Wayne E. "Book Review: Dictionary of Christinity in America Edited by Daniel G. Reid, Robert D. Linder, Bruce L. Shelley, Harry S. Stout, Westmont, Illinois: InterVarsity Press, 1990, p, 1305." A/G Heritage. Springfield, Missouri, 1991.

Whitehouse, Harvey. Modes of Religiosity: A Cognitive Theory of Religious Transmission. Lanham, Maryland: Rowman Altamira, 2004.

Yanagida, Mitsuhiro. "The Role of Model Organisms in the History of Mitosis Research." Cold Spring Harb Perspect Biol 6, no. 9 (2014). 